\title{
Analysis on the Current Situation of Poor College Students Financing System
}

\author{
Aichen Liu \\ Jilin Agricultural University Jilin Changchun \\ 9558805@qq.com
}

Keywords: Colleges and universities; Poverty; College students; Founding

\begin{abstract}
At present, the poor students in Colleges and universities in our country get more and more attention and care and will exist in a short time for a variety of reasons. This article mainly carries on the analysis through to the current university student poverty situation and the current aid system and research on the problems existing in the financial aid system for poor students, on the basis of the analysis to explore the University poor student financial aid system for the further improvement of the countermeasures and suggestions.
\end{abstract}

\section{Introduction}

With the rapid growth of the market economy and the improvement of the living standards of the people, but there are still a lot of people living in poverty. In recent years, the new characteristics of poor students in Colleges and universities have emerged, because the economic poverty problem has gradually developed into a variety of reasons, such as psychological problems, ideological problems, academic barriers and employment pressure. How to make the poor college students successfully complete their education, cultivate healthy personality, so that they can equal participation in academic learning and equal employment competition, which has become a very important content in the work of colleges and universities. Whether can actively and properly do a good job in poor college students funded work related to the further reform and development of colleges and universities, the smooth implementation of educational equity, the relationship between the stability of colleges and universities, and even related to the stability and development of society.

\section{The Poverty Situation of College Students}

Affected by a variety of factors, at this stage there is no exact data on the statistics of the poor college students in China, however, through the analysis of a variety of channels and different levels of statistical results, you can estimate that the current proportion of college students in poverty is about 20\%-25\%. And in 2015 the size of the national college students is about 40 million 180 thousand people, according to which, the number of poor students can be worked out for the number of 800-1000 million.

Related statistical analysis, the sex ratio of poor college students by boys: girls are 1.86:1. The proportion of poor college students from rural and underdeveloped area accounted for $62.8 \%$ and $20.5 \%$, the municipalities directly under the central government accounting for $6.6 \%$, open coastal city accounting for $7.7 \%$, accounted for $2.4 \%$ from other regions. Poor university student's family members constitute, single parent families and parents of the dead family of $3.6 \%$ of the proportion, three home of the proportion of $21.2 \%$, and the number of family population of 4 people, 5 people, more than 6 people were $8.6 \%, 21.9 \%, 34.6 \%$, respectively. In terms of family income of poor college students, $50.1 \%$ of poor families take agriculture as the main source of income, $38.6 \%$ of poor families with wages as the main source of income, $3.1 \%$ of poor families in the business and financial sector as the main source of income, and other sources of income for the family of $8 \%$. From the analysis of the distribution characteristics of poor students, almost $65 \%$ of the college students are poor students from the ordinary workers, farmers and family. 


\section{Problems Existing in the Financing System of the Current Poor College Students}

Country Aspect. In the poor university student funding system, funding is the main channel of national funding, but the state funding is obviously inadequate. Relevant statistical data shows, in the student funding, nearly $60 \%$ of the national funding, about $20 \%$ of the school is relying on self, and social contributions of funds is about $20 \%$. Therefore, the funding for poor students in Colleges and universities has formed a strong dependence on the country. China's funding system is not yet perfect, cannot effectively play the function of coordination and guidance. At present, in the majority of colleges and universities, the poor students as a special group, for major colleges and universities, in the process of funding, often encounter a variety of problems, which greatly affect the smooth development of its education management.

Social Aspects. Because of the relevant policies and supporting measures of student loan in our country is not perfect, in this case, the financial institutions in terms of loan management is bound to face a certain policy risk. And student loan takes a credit, which is not a mortgage with no guarantee but the risk is very large, and it simply cannot control. Because the country implement the policy of student loans, and require commercial banks to actively cooperate, however, the lack of effective measures to help commercial banks to avoid various risks, to ensure the economic interests of commercial banks, in this case, the commercial banks will not actively issue student loans. In addition, funding for poor students, the enthusiasm of social organizations and individuals is uncertain, but also limited.

School Aspects. First, there is no correct understanding of the function of the financial aid system, in the process of designing the fund system and specific operation, often do not attach great importance to the cultivation of poor college students' quality, social responsibility and independent spirit, at the same time, the work is also taken by the same way, that is only to help the economy of poor students, but did not give full play to its educational function; Two, there are some deficiencies in the system design. Three is not clearly defined for poor students, in the actual economic situation of poor college students, colleges and universities did not carry out accurate and scientific assessment, but also does not clearly define the standard of poor students, poor students will inevitably increase the randomness, and the specific operation is the lack of transparency, eventually leading to poor students who really need help, but cannot get funding. Some system design has brought bad influence to the poor students, taking the scholarship as an example, the majority of poor students from which the economy and education is relatively backward areas, the lack of a good foundation of culture, which is difficult to obtain good learning results, in fact, the poor college students in higher grades, students only occupy a very low proportion, therefore, most of them are difficult to get a scholarship, three is not clearly defined for poor students, in the actual economic situation of poor college students, colleges and universities did not carry out accurate and scientific assessment, but also does not clearly define the standard of poor students, poor students will inevitably increase the randomness, and the specific operation is the lack of transparency, eventually leading to poor students who really need help, but cannot get funding.

Student Aspects. Firstly, some poor students have a strong dependence on psychology, has formed a deep-rooted idea of // waiting for, depend on, requiring to", and is not able to do hard work, do not want to work with the help of the platform, through their own labor in exchange for a certain learning costs and cost of living; secondly it is poverty that makes these college students form a kind of inferiority complex, which is affected by the psychological pressure, so their performance is often behind the ordinary students, cannot get the scholarship funding; thirdly, is the establishment of the national and school funding system does not form a correct understanding, lot of college students do not belong to the real poor students, using false information to obtain the trust of the school, will be their own into the ranks of poor students, so as to get the corresponding student loans; Fourthly a lot of poor college students lack integrity the repayment period, usually cannot actively repayment, and there are some poor college students deliberately do not repay, so that banks and other financial institutions lost the confidence of poor college students to carry out student loans. 


\section{Countermeasures for the Construction of Financial Aid System for Poor Students in Colleges and Universities}

Nation Aspects. Establish a variety of loan models. The national student loan is mainly supported to the "basic needs" of the "financial difficulties students", general student loans mainly serve the students whose economy is not very difficult, but there is a demand for development. The national student loan may be handled by the designated financial institution, the implementation of financial subsidies and government guarantee are a kind of credit policy. General student loans can be handled by all financial institutions willing to handle the business, without fiscal interest discount and implementation of the general interest rate, which can be guaranteed by the parents or relatives.it is a kind of commercial loans. These two types of loans in close coordination, can meet the needs of multi-level student funding needs, but also can mobilize the enthusiasm of all types of financial institutions.

Establish and improve the incentive and restraint mechanism. In the implementation of incentive and restraint mechanisms, not only to emphasize fairness, but also should focus on efficiency, which will be a combination of fairness and efficiency. Therefore, in the design of incentive mechanism, should learn from the scholarship, inclined to poor students, those excellent in character and learning at the same time, to expand the scope of funding, should at least cover $50 \%$ of the poor college students. And it should also encourage poor students to work in poor areas and in some tough industries through grants. And in the design of the restraint mechanism, it should be based on compensatory mechanism, that is, for those students who get grants, should be in school during the time to take some time to engage in related social welfare, can also pay a certain amount of education resources sharing tax after graduation, so as to make due contributions to the state and society.

Legal guarantee. Make the laws and regulations related to the work of the poor college students' aid work as soon as possible. Wanting to improve and perfect the poor students funding work, the country should be based on student channels continue to expand with the corresponding laws and regulations, so that the poor students work. Countries and universities should be based on the actual situation of the local, the introduction of standards for poor students, as well as on the prize, loan, help, subsidy, exemption, the implementation details of various funding methods.

Social Level. Broaden the funding target. With the acceleration of economic globalization, the competition among talents is becoming more and more fierce, therefore, colleges and universities should broaden their own goals, not only to "economic hardship", but also should be "economic", will be funded system in the "economic" function to fully play out. For example, the university should support those outstanding undergraduate students to participate in some scientific research activities, and encourage students to actively participate in the design of entrepreneurship, entrepreneurial activities, and provide some scientific research funds for them, also to provide low interest loans, so as to cultivate more talents.

Improve the poor students identification procedures. In the process of establishing a file for the poor college students, it is necessary to do a good job in the examination and approval of the poor college students, and track the actual family economic changes in poor college students, and then on the basis of this, to make reasonable adjustments to the scope and manner of funding. In this way, can avoid poor college students in the school for four years has been enjoying the benefits of the situation, also can help poor students in the sudden difficulties families, so as to those who really need to subsidize poor college students.

School. Firstly, the credit and poor student funding linked. Colleges and universities should be innovative talent training model, build a flexible credit system, that is based on the school curriculum, to carry out the registration and management of students and other work, to make poor college students can choose their learning life according to their own economic conditions, so in this way, it is able to achieve while learning, while working, you can work to accumulate a certain material foundation, then learn. At the same time, under the credit system, poor college students are also able to work and study, which is likely to lead to an extension of the educational system, however, it does not affect their professional knowledge, learning ability, and it will also not affect 
their psychological state.

Secondly, the science and technology activities and poor students funding linked to each other. Universities should actively encourage and support the poor university students to join the extracurricular activities, and give a certain reward as a reward, but in this process should strengthen the quantification of assessment criteria. For example, if a article are published in the National Journal magazine, the poor college students will be able to obtain the corresponding grants. This approach not only helps to solve the financial problems of poor college students, but also is conducive to the development of poor students themselves, but also to improve the visibility of the school.

Thirdly, enrich student activities. Poor college students can not only participate in work study, but also should establish some self-management, self-education, self-service and other mechanism such as, dormitory management, campus management, environmental inspec.to In addition, many colleges and universities have a convenience store in the campus, you can make poor students to operate, so as to obtain a number of learning and living expenses.

Student Aspects. In recent years, the loan repayment of student loans has been not optimistic, and the poor university students' personal integrity has also caused that the commercial banks do not trust, fundamentally speaking, mainly because our country has not yet built a personal credit system, the relevant social control mechanism is not perfect. Therefore, our country should be based on a professional web site to establish a consultative platform, in the scope of the law to gather the personal credit information in banks and schools and other social aspects to process, storage and analyze, to provide services for the Ministry of education and the Ministry of finance, and to provide consulting and evaluation services to the credit and credit standing of the university students in various aspects of the society. In addition, for dishonesty and fraud, should increase the punishment. Strict punishment is the key to establish and improve the credit system of College Students.

\section{References}

[1] J.M.Liu and R.M.Qiu.A Brief Discussion on the Structure and Characteristics of the Current College Student Financial and System in China [J]. Journal of Jiujiang Vocational and Technical College, 2012, 01:71-72+78.(In Chinese)

[2] R.L.Chen. A Discussion on the Reform of the Poor College Student Financial aid System [J].Human Resource Management, 2013, 10:248. (In Chinese)

[3] L.Z.Gao. Study on the Problems and Countermeasures of the Poor Students Funding System in China [D]. Qingdao University of Science \& Technology, 2010. (In Chinese)

[4] H.M.Li. Think about the Perfection of the Trinity of Poor College Students' aid System [J].Journal of Heilongjiang College of Education, 2013, 05:21-22. (In Chinese)

[5] S.F.Zhang. Discussion on the Countermeasures of Improving the Financial Aid System for Poor Students in Colleges and Universities [J].Contemporary Education Forum (comprehensive study), 2011, 02:67-70. (In Chinese) 